population growth and the impacts of globalization. This situation will pose at least two major challenges to African governments-namely, developing and sustaining ICT infrastructure and skills for the expansion of technology-based delivery modes and enhancing the quality of higher education provision. The various initiatives highlighted in the previous section indicated that the challenge of ICT infrastructure and skills is being addressed adequately. The issue of quality is being approached at least through two major strategies-the adaptation of existing quality assurance and accreditation frameworks in response to the emerging delivery modes or the development of new ones and the reversal of the phenomenon of brain drain.

\section{Chile: Accreditation versus Proliferation}

\section{ANDRÉs BERnasCon I}

Andrés Bernasconi is associate professor at the Institute of Policy Studies, Universidad Andrés Bello, Chile. Address: Av. República 330, Santiago, Chile.E-mail: abernasconi@unab.cl.

$\mathrm{I}^{\mathrm{n}}$ October 2006, after four years of deliberation in Congress, Chile's new Quality Assurance Act (QAA) was signed into law. The act organizes an accreditation system for higher education programs and institutions and reflects a compromise between highly divergent philosophies of regulation. The leftof-center administration and its allies in Congress promoted accreditation as the responsibility of a national, public, and specialized agency. The right-wing opposition, in turn, supported a regulated marketplace of private accreditation agencies that institutions and their programs could freely choose to engage. The outcomes means that the accreditation of institutions (akin to the US regional accreditation) will be carried out by a public national accreditation commission, composed mostly of academics. Accreditation of undergraduate, master's, and doctoral programs will be undertaken by private accreditation agencies, national or foreign, licensed and supervised by the commission.

In accordance with the QAA, accreditation is voluntary, except in the case of undergraduate programs in medicine and education, for which accreditation is mandatory. If a program in these fields is not accredited, its students are not eligible for state-supported financial aid. While institutions can choose not to be accredited, a student aid law passed last year-also an example of Chile's "carrot" approach to regulation-makes accreditation of institutions (not programs) a condition for students to have access to private educational loans warranted by the government.

\section{The Current Context}

The main impetus behind Chile's QAA was a second wave of unruly expansion of higher education provision. The first boost came in the early I990s-in part a consequence of the hasty licensing (i.e., initial authorization to operate) of dozens of new private institutions in the final months of the Pinochet regime (I973-I990). Private growth regained momentum with the turn of the new century when most private institutions were granted, after a decade of close supervision by a licensing board, full autonomy to open new degree programs and campuses without prior academic review. In practice, as private institutions achieved full autonomy, higher education provision became deregulated; public universities were never subject to any licensing requirements and operated with full autonomy all along.

While subject to regulatory oversight, private universities' expansive thrusts could be effectively reined in. However, as soon as this supervision ended, many institutions sought avidly to make up for their loss of market share by offering everything everywhere. Students matriculated in private universities doubled their numbers between 2000 and 2005 . Several private universities experienced a fourfold or higher increase in the numbers of their students in the same period. Nonselective public institutions rapidly followed suit, and a sort of arms race broke out to capture students, which in the end drove overall higher education enrollments up by more than 30 percent between 2000 and 2005 .

For a country whose higher education institutional base is 90 percent private, with over two-thirds of students matriculated in the private sector, and with public universities also

Chile joins Argentina, Colombia, El Salvador, and a handful of other countries in Latin America that in the last decade have organized accreditation systems for public and private institutions.

dependent on tuition fees, the ongoing expansion of higher education is not a surprising development: students are the lifeblood of the market system. Yet even the most ardent defenders of private initiative and private funding in education had to concede that this new expansion was coming at the expense of quality, precisely when the low performance level of Chile's education, as compared to newly industrialized countries, had become one of the most salient policy concerns across the political spectrum. The context was, therefore, favorable for the introduction of some form of quality assurance for the newly autonomous private institutions and public institutions that had overextended their entrepreneurial drive.

\section{Accreditation as Delayed Regulation}

With this new law, Chile joins Argentina, Colombia, El 
Salvador, and a handful of other countries in Latin America that in the last decade have organized accreditation systems for public and private institutions-separate from the licensing requirements covering only new private institutions. This step is, in part, a regional response to universal trends: globally, quality assurance is on the rise. Driving these regional initiatives are worldwide trends, such as accountability, the pressures of greater competitiveness, the mounting need of institutions to differentiate themselves, and the increasing power of management in universities. Imitating fashionable reform is, of course, a factor as well.

In Latin America these initiatives seem to share the realization that licensing alone fails to maintain pressure on institutions to monitor and improve quality. First, because they are usually exempt from licensing strictures, public institutions are allowed to act irresponsibly if they so choose. Second, licensing regulations for private institutions often come with an expiration date, after which freedom is either absolute or substantial (whatever the market would bear).

Given that in most of Latin America licensing standards for new private institutions of higher education have been weak or absent, this surge in accreditation schemes follows the expansion of the unregulated private sector. In this sense, accreditation functions as a sort of delayed regulation, an ex post facto attempt to tighten control over the worst examples of proliferation.

Whether the new Chilean law will succeed in fostering quality in higher education is anybody's guess. The QAA builds upon successful pilot experiences carried out since the I990S to test different approaches to accreditation, and this is reason to be optimistic. However, the new law may be just another station in an endless loop of unacceptable performance. The regulatory response eventually gives way to new forms of questionable practices and in turn to new controls, in a game driven by the marketplace.

\section{The Dilemma of Higher Education in Burma}

\section{RICHARD MARTIN}

Richard Martin is a higher education consultant who was previously education, science and training counselor at the Australian Embassy in Hanoi and a consultant on a World Bank Project in Vietnam. Address: PO Box 2065, Clovelly, West, NSW, Australia, 2031. E-mail: rmartin@unwired.com.au or rjmartin50@hotmail.com.

$\mathrm{B}$ urma is a pariah state, shunned internationally because of its rejection of democratic institutions and its poor human rights record. As a result, its higher education system remains limited and antiquated, with only a few Burmese young people getting the opportunity to study abroad or to be exposed to modern international scholarship. But despite the policies of the government and sanctions of the international community, some opportunities now exist for Western universities and nongovernmental organizations to engage with Burma and to have a positive influence on its next generation.

Burma has a population of over 50 million, of which 60 percent are under the age of I 8 years. It suffers from border, ethnic minority, health, and education problems that the military junta refuses to address. This poses a sharp contrast to the country of promise, progress, and significant influence only 40 years ago.

\section{Education and Social Issues}

Today, there are increasing pressures for higher education reform to address the needs of Burmese students. The Ministry of Education, however, lacks credibility and like all ministries is headed by military personnel who have limited knowledge of their portfolios. Similar situations existed in countries such as Indonesia only I5 years ago, but aid was still being provided by the Asian Development Bank, the World Bank, and nongovernmental organizations.

\section{Burma is a pariah state, shunned internationally} because of its rejection of democratic institutions and its poor human rights record.

Western nations have focused on human rights issues, and overseas development assistance has trickled down to basic support from UNICEF (the United Nations Children's Fund) to the health sector. The World Bank and the Asian Development Bank do not provide any assistance. The Association of Southeast Asian Nations has been pitiful in its approach, avoiding pressure that would encourage Burma to accept change.

The higher education sector has been deliberately neglected by the present government, whose priority is to retain political control, not only to safeguard its economic advantages but also to suppress ethnic minorities and democratic groups from action that might split the nation or cause civil disturbance. However, as in Cambodia, tourism offers opportunities for education and training assistance since this sector is seen as noncontroversial and one from which the country can benefit. E-education offers possibilities; however, access to the Internet is still limited and restricted.

The US government estimates that only 40 percent of the population has access to basic education. Few students continue on to secondary education and fewer to vocational education training or to higher education. Furthermore, reaching the end of secondary education in Burma prepares only a few to enter 